\title{
Introductory Remarks by Georg Nolte
}

\author{
Chair of the International Law Commission at Its Sixty-Ninth Session
}

Our program indicates that the speeches before the coffee break were part of a "solemn meeting". Now it is my duty to introduce you to what may be a less solemn, but which is an equally important part of our anniversary celebration events. In fact, the five panel discussions which follow are the core of what the Commission envisaged when it conceived a series of events with the aim of "Drawing a balance for the future".

"Drawing a balance for the future" signals an ambition. The ambition is to commemorate, on the occasion of the anniversary, but not to simply do so in a self-congratulatory manner. Rather the ambition is to use the occasion for reflections to prepare the Commission for challenges which lie ahead. Such challenges may have their roots in the past and the present.

When I joined the Commission eleven years ago, the Commission was facing its sixtieth anniversary. A sixtieth anniversary is not as important as a fiftieth or a seventieth anniversary, simply because of the magic of the numbers. This lesser character of the anniversary may have been the reason why the Commission, at the time, only organized a small official event, here in Geneva, which has left no traces in the form an official publication. ${ }^{1}$ But there may have been deeper reasons for this lesser form of celebration than just the magic of the numbers. In fact, at the time, there was a certain sense of crisis. This sense of crisis was well expressed in the title of an academic article, which read: "The International Law Commission - An Outdated Institution?". 2 The author of the article was Christian Tomuschat, our former colleague. I am particularly happy that he has joined us today. In this article, Tomuschat expressed skepticism about the future role of the Commission. He wondered what was left for the Commission to do after the most important areas of general rules of international law had been more or less successfully progressively developed and codified by the Commission. This article reflected well the mood which prevailed at the time. There was then a certain sense of stagnation and a crisis of self-confidence of the Commission.

1 However, an unofficial colloquium among the members of the Commission, together with invited academics, has also taken place on that occasion, in Munich, whose proceedings are published in Georg Nolte (ed), Peace through International Law - The Role of the International Law Commission. A Colloquium at the Occasion of its Sixtieth Anniversary (Springer 2009).

2 Christian Tomuschat, 'The International Law Commission - an Outdated Institution?' (2006) 49 GYIL77. 
Today, the situation seems to be very different. The Commission is dealing with so many topics that it can hardly manage. Even the once holy coffee breaks have this year been canceled for weeks. The Commission is dealing with important topics, and it is dealing with them at a higher speed than in previous times. The number of proposed new topics exceeds the capacity of the Commission. If I am not mistaken, the members of the Commission are more active on average than ten years ago, at least if we compare the degree of participation in the Drafting Committee on the various topics. And it is perhaps also an important sign that the Commission attracts more young people than ever before who are interested to work as assistants of the members.

So, is the Commission in a better condition at age seventy than it was at age sixty? Maybe, but we should not be too certain. One of the purposes of our colloquium today is to diagnose the state of health of the Commission and the situation in which it is. As any reasonable seventy-year-old, the Commission has decided that it should not try to perform a self-diagnosis, but rather go to recognized experts and have itself and its situation checked by them. The Commission has therefore invited reputed academics, some long established and some more recently established, to provide it with in-depth analyses of different aspects of its work. And the Commission wishes to have these analyses discussed and probed by our most important constituents, which are the Legal Advisers of States and international organizations.

The purpose of our discussions today thus goes beyond an exchange of views, and beyond having pleasant meetings during the coffee breaks and the receptions. The main purpose of our discussions is to produce a lasting impulse which will serve to improve and to safeguard the role of the Commission in its unique role of progressively developing and codifying international law. We will try to turn today's colloquium into a lasting impulse by two followup activities: First, a report of our discussions here will be produced and presented later this year in New York, during the International Law Week, to the delegates in the Sixth Committee, to stimulate further discussion. Even more importantly, the written contributions of our speakers and the proceedings of our discussion will be published as a book. This book will provide an important reference point for further debates in broader circles about the performance of the Commission in achieving its mandate, perhaps even playing a role in the context of the future eightieth or hundredth anniversaries of the Commission.

There are, of course, limits to what we can do as a Commission. The international political context is currently quite turbulent. Some even say that that this context bodes ill for the progressive development and the codification of international law. These turbulences may affect the Commission, directly as well as in more subtle and indirect ways. It is thus possible that an increased 
activity of the Commission is not met with a corresponding receptivity on the part of States, their courts, international organizations and other actors. The only means by which the Commission can respond to broader challenges for the international rule of law, it seems to me, is to base its work on authoritative sources, to present its work in a transparent and well-argued fashion, and to maintain its cohesion as a voice, which reminds States and other actors that there is a common basis from which peaceful and fruitful international relations need to be conducted in the common interest of all.

The titles of the five panels are focused on questions of immediate interest for the Commission, but each of those topics is affected by broader political and other developments. This is certainly true for the first panel, "The Commission and its impact", which squarely forces us to look beyond the Commission itself, and to reflect on its role in relation to its addressees and international law as a whole. The second panel on "The working methods of the Commission" seems to focus on more technical matters, but I suppose that it will turn out that the working methods are also mirrors, or symptoms, of more general principles and developments. The third panel on "The function of the Commission: How much identifying existing law, how much proposing new law" addresses one of the classic questions for the Commission, a question which has acquired a new significance in the face of the fact that the products of the work of the Commission are today more frequently used by national and regional courts. The fourth panel on "The changing landscape of international law" also addresses matters which are currently high on the agenda of the Commission, which is how to prioritize among the multitude of possible areas in which the Commission might contribute. The title of the fifth panel on "The authority and the membership of the Commission" may be read as suggesting that there is a connection between the authority of the Commission and its membership, but the panelists should, of course, feel free to question whether and how far this is actually the case.

I wish us all instructive and stimulating debates. And with this may I invite the Chair of the first panel, our former colleague and good friend, Ambassador Comissario Afonso, to take the floor together with his fellow panelists! 
Chair of the International Law Commission at Its Sixty-Ninth Session - 9789004434271 Downloaded from Brill.com04/26/2023 05:58:16AM via free access 